\title{
Efficacy of Leaf Oil from Pimenta racemosa var. racemosa in Controlling Bacterial Wilt of Tomato
}

Péninna Deberdt, ${ }^{\dagger}$ Isabelle Davezies, Régine Coranson-Beaudu, and Alexandra Jestin, CIRAD, UPR HORTSYS, Campus AgroEnvironnemental Caraibe, F-97285, Le Lamentin, Martinique, France

\begin{abstract}
Bacterial wilt, caused by Ralstonia solanacearum, is a major plant disease throughout the Caribbean. The ability of the essential oil from Pimenta racemosa var. racemosa to control bacterial wilt of tomato (R. solanacearum, phylotype IIB/4NPB) was investigated. Lemongrass (chemotype 1)-, aniseed (chemotype 2)-, and clove (chemotype 3)scented chemotypes of $P$. racemosa var. racemosa essential oil were tested. Six concentrations of emulsified essential oil (from 0.01 to $0.14 \%[\mathrm{v} / \mathrm{v}])$ were evaluated by in vitro culture amendment assays and by in vivo experiments in greenhouse. Chemotype 3 displayed remarkable in vitro antibacterial activity against $R$. solanacearum, because the

minimum inhibitory concentration was only $0.03 \%$, compared with $0.14 \%$ for chemotypes 1 and 2. In greenhouse experiments, no incidence of bacterial wilt was observed in tomato plants grown in soil treated with chemotype 3 of $P$. racemosa var. racemosa at a concentration of $0.14 \%$. In the untreated control soil, $62 \%$ of plants displayed symptoms of bacterial wilt. Treatment with chemotype 3 significantly increased the growth of tomato plants compared with untreated controls. These results suggest that chemotype 3 of $P$. racemosa var. racemosa essential oil is a good candidate for further development as a soil biofumigant for the control of tomato bacterial wilt.
\end{abstract}

Bacterial wilt, caused by Ralstonia solanacearum (Yabuuchi et al. 1995), affects more than 50 plant families worldwide, including the family Solanaceae (Denny 2006; Hayward 1991). In Martinique (French West Indies), R. solanacearum causes major economic losses on vegetable crops, especially tomato. In 1999, an emerging population of $R$. solanacearum belonging to phylotype IIB, sequevar 4NPB appeared (Wicker et al. 2007). The IIB/4NPB population is more aggressive than the populations already present on the island and has a wider host range, including members of the families Solanaceae, Cucurbitaceae, and Anthurium (Wicker et al. 2007, 2009b).

Current management strategies for the control of tomato bacterial wilt are not efficient, because it is a soilborne systemic disease and no chemical treatments can be used effectively for managing $R$. solanacearum by direct field application. Recent studies reported that the IIB/4NPB emerging population of $R$. solanacearum can overcome the existing sources of resistance in tomato cultivars (Lebeau et al. 2011; Wicker et al. 2009a). In Martinique, no commercial tomato cultivars are resistant to this emerging strain and the tropical environmental conditions favor the development of the disease, rendering its control even more difficult. Thus, there is an urgent need to identify effective ways of controlling the disease.

Plant-derived compounds are possible candidate substances for the management of $R$. solanacearum through direct application in the field. The antimicrobial activity of natural plant products against plant pathogens has been extensively investigated worldwide and the results are promising (Abdel-Monaim et al. 2011; Abo-Elyousr and Asran 2009; Bajpai et al. 2010; Balestra et al. 2009; Bi et al. 2012; Bowers and Locke 2004; Deberdt et al. 2012; Hashem et al. 2010; Kishore et al. 2007; Lucas et al. 2012; Moghaddam et al. 2014). Essential oils have long been used in traditional medicine for their antimicrobial properties (Raut and Karuppayil 2014). Several previous studies have shown that essential oils can be used in the management of bacterial wilt disease. In field experiments, Ji et al. (2005) showed that using some volatile compounds derived from plants, such as palmarosa essential oil and the purified active compound of thyme oil (thymol), provided disease control. In greenhouse tests, Paret et al.

${ }^{\dagger}$ Corresponding author: P. Deberdt; E-mail: peninna.deberdt@cirad.fr

Accepted for publication 7 August 2017.

() 2018 The American Phytopathological Society
(2010) found that palmarosa and lemongrass oils inhibited the growth of $R$. solanacearum (race 4, phylotype 1) in potting medium and reduced the incidence of bacterial wilt of edible ginger. Huang and Lakshman (2010) demonstrated that clove oil reduced bacterial wilt of tomato and geranium plants in greenhouse conditions. A recent study (Alves et al. 2014) showed that biofumigation with palmarosa essential oil reduced the severity of bacterial wilt of sweet pepper in both greenhouse and field experiments.

Pimenta racemosa var. racemosa belongs to the myrtle family (Myrtaceae) and is native to the French West Indies. Essential oils from the leaves of $P$. racemos $a$ var. racemosa have traditionally been used for medicinal purposes. $P$. racemosa var. racemosa produced three chemotypes with different physical characteristics and chemical compositions (Abaul and Bourgeois 1995). Aurore et al. (1998) reported differences in the antimicrobial activities of the three chemotypes of $P$. racemosa var. racemosa against human bacterial pathogens, suggesting that chemotype plays an important role in explaining differences in the antimicrobial activities of the essential oils. However, to date, no studies have reported on the antibacterial properties of the three chemotypes of $P$. racemosa var. racemosa against phytopathogenic bacteria such as $R$. solanacearum.

Thus, the aims of this study were to (i) evaluate the antibacterial effect of three chemotypes of essential oils of $P$. racemosa var. racemosa from the French West Indies on an emerging strain phylotype IIB/4NPB of $R$. solanacearum in vitro, (ii) develop an efficient in vivo soil treatment to reduce the incidence of tomato bacterial wilt, and (iii) investigate the effects of the essential oil on the vegetative growth of tomato plants.

\section{Materials and Methods}

Two laboratory tests and three greenhouse assays were conducted at the Campus Agro-Environnemental Caraibe, Martinique. The aim of the laboratory tests was to select the chemotype oil of $P$. racemosa var. racemosa with the most effective antimicrobial activity against $R$. solanacearum. The aim of the in vivo experiments was to evaluate the effect of preplanting treatment of the soil with selected essential oils of $P$. racemosa var. racemosa on the population dynamics of $R$. solanacearum in the soil, the development of bacterial wilt in tomato, and on the vegetative growth of tomato.

Bacterial strain and preparation of the inoculum. All of the experiments were conducted with the highly virulent $R$. solanacearum strain CFBP 6783 belonging to the emerging population phylotype IIB/4NPB (Wicker et al. 2007), which was isolated from a diseased Heliconia sp. in Martinique. The bacterium was grown on casamino 
acid peptone glucose medium agar plates (Hendrick and Sequeira 1984) at $28^{\circ} \mathrm{C}$ for $48 \mathrm{~h}$. It was then washed from the plates and suspended in sterile distilled water. The bacterial suspension was adjusted to optical density at $600 \mathrm{~nm}=0.1$ (corresponding to about $10^{8}$ cells $/ \mathrm{ml}$ ) using a spectrophotometer (Biochrom AG Cell Density Meters; Fisherbrand).

Plant essential oils. Three chemotypes of $P$. racemosa var. racemosa essential oil (chemotype 1 with a lemongrass scent, chemotype 2 with an aniseed scent, and chemotype 3 with a clove scent) were purchased from the Association Le Mapou (Terre de Bas, Guadeloupe, French West Indies). The essential oils were isolated from crushed leaves by hydrodistillation. The essential oils used for this study were emulsified in Tween 20 (ratio 1:1), as described by Paret et al. (2010), to enhance the solubility of the oils.

Natural soil. The soil used in these studies was a natural Nitisol type soil taken from the upper 15-cm layer of a field located at the CIRAD station in Rivière Lézarde, Martinique (Nitisol; 86.0\% clay, $5.3 \%$ alloysite silt, $10.9 \%$ sand, and $4.55 \%$ organic matter [pH 5.5]). The soil was sun dried for 4 days and sieved to $5 \mathrm{~mm}$.

In vitro culture amendment assays. The three chemotypes of $P$. racemosa var. racemosa essential oils were used to test the in vitro effect of the chemotype on $R$. solanacearum growth. The minimum inhibitory concentration of chemotype 3 on $R$. solanacearum in vitro growth was then determined. Stable oil emulsions previously prepared in Tween 20 (ratio 1:1), as described by Paret et al. (2010), were added to the agar medium. The concentrations tested ranged from 0.01 to $0.14 \%$ (v/v). Thus, these concentrations refer to the concentration of the emulsified essential oils including Tween 20 as emulsifying agent, as recommended by Griffin and Markham (2000). A preliminary test was conducted to study the effect of the varying Tween 20 concentrations on the growth and survival of $R$. solanacearum. Tween 20 was mixed with sterile distilled water (ratio 1:1) and 2 to $28 \mu \mathrm{l}$ of this mix was added to $20 \mathrm{ml}$ of liquid modified semi-selective medium from South Africa (SMSA) (Engelbrecht 1994) to give six final concentrations from 0.01 to $0.14 \%(\mathrm{v} / \mathrm{v})$. Because no significant differences were observed in $R$. solanacearum populations between the Tween treatments and the control, we performed the tests using one control with the same concentration of Tween 20 as that used in the $0.14 \%$ of emulsified essential oil: $20 \mathrm{ml}$ of liquid media was amended with $28 \mu \mathrm{l}$ of the mix (Tween 20 and sterile distilled water at a ratio of 1:1). In the experiment conducted to test the effect of the chemotype on $R$. solanacearum, $20 \mathrm{ml}$ of liquid modified SMSA medium was amended with $8 \mu \mathrm{l}$ of the emulsified oils to give a final concentration of $0.04 \%$ (v/ v). Similarly, 14 and $28 \mu \mathrm{l}$ of the emulsified oils were added to $20 \mathrm{ml}$ of medium to give final concentrations of 0.07 and $0.14 \%(\mathrm{v} / \mathrm{v})$, respectively. In the experiment to determine the minimum inhibitory concentration, $20 \mathrm{ml}$ of liquid modified SMSA medium was amended with 6,4 , and $2 \mu l$ of the emulsified oil to give final concentrations of $0.03,0.02$, and, $0.01 \%$ (v/v), respectively. Plates with Tween 20 but without essential oils were used as controls. The medium was poured into each Petri dish and dried for $20 \mathrm{~min}$ in a circulating laminar flow hood, as described by Paret et al. (2010). For in vitro analysis of the effect of the essential oils on $R$. solanacearum, $100-\mu 1$ aliquots of the pathogen suspension ( $R$. solanacearum inoculum at $\left.10^{8} \mathrm{CFU} / \mathrm{ml}\right)$ were diluted 10 -fold $\left(10^{-1}\right.$ to $\left.10^{-7}\right)$, plated on the medium, and incubated at $28^{\circ} \mathrm{C}$. The $R$. solanacearum populations were assessed after 48 and $72 \mathrm{~h}$ of incubation. The CFU were counted in a pathogen suspension corresponding to $10^{3} \mathrm{CFU} / \mathrm{ml}$. The values were adjusted to the original concentration of $R$. solanacearum inoculum $\left(10^{8} \mathrm{CFU} / \mathrm{ml}\right)$, as described by Paret et al. (2010). Each treatment was replicated with three plates. Experiments were conducted twice.

Soil inoculation and application of essential oil. The in vivo experiments were performed in a greenhouse with a night temperature of $28^{\circ} \mathrm{C}$ and a day temperature of $35^{\circ} \mathrm{C}$. Pots (capacity of 0.4 liter) were filled with $400 \mathrm{~g}$ of dry soil, and $80 \mathrm{ml}$ of sterile water was added to each pot to moisten the soil. In the experiments designed to investigate the density of $R$. solanacearum populations in the soil and control of the disease by the essential oil, the soil in each pot was inoculated by adding $10 \mathrm{ml}$ of the $R$. solanacearum inoculum solution (optical density at $600 \mathrm{~nm}=0.1$, corresponding to about $10^{8}$ $\mathrm{CFU} / \mathrm{ml}$ ) to obtain a final estimated population of $2.5 \times 10^{6} \mathrm{CFU} / \mathrm{g}$ of dry soil. In the experiment designed to investigate the effect of the essential oils on the vegetative growth of tomato plants, the soil was not inoculated with $R$. solanacearum.

Treatment with essential oil. Chemotype 3 of $P$. racemosa var. racemosa essential oil was used for all experiments. The essential oil was applied by drenching the soil in each pot with $10 \mathrm{ml}$ of emulsified essential oil at a concentration of $0.04,0.07$, or $0.14 \%$. The untreated control received sterile water instead of essential oil, plus Tween 20 (at the same concentration as that used in the treatment with $0.14 \%$ of emulsified essential oil).

Essential oil $(160 \mu \mathrm{l})$ was emulsified separately in Tween 20 (at a ratio of 1:1), mixed thoroughly in $10 \mathrm{ml}$ of sterile water, and distributed evenly over 0.4 liter of natural soil to give a final concentration of $0.04 \%$ (v/v) of emulsified essential oil, as described by Paret et al. (2010). Similarly, 280 and $560 \mu l$ of the oil were emulsified in Tween 20 and mixed in $10 \mathrm{ml}$ of water to give final concentrations of 0.07 and $0.14 \%(\mathrm{v} / \mathrm{v})$, respectively, of emulsified essential oil. In each treatment, the pots were covered with aluminum sheets to limit the escape of volatiles. The duration of the treatment was 7 days, after which the aluminum sheets were removed and the pots were left uncovered for 3 days to allow excess volatiles to escape. Three-weekold susceptible 'Heatmaster' tomato plants (Seminis Seeds) were transplanted 10 days after the soil was treated with essential oil.

Population density of $R$. solanacearum in soil treated with essential oil. The bacterial population was counted $0,1,3,7,10$, and 14 days after the inoculated soil was treated with emulsified essential oil. On each occasion, the soil was first mixed using a clean wooden stick; then, $5 \mathrm{~g}$ of soil was collected and suspended in $25 \mathrm{ml}$ of buffered soil dispersion solution $(0.1 \mathrm{M} \mathrm{NaCl}, 0.01 \%$ sodium dodecyl sulfate, and $0.1 \%$ sodium pyrophosphate [pH 7.2]) (Van Elsas and Smalla 1997), shaken at $100 \mathrm{rpm}$ for $30 \mathrm{~min}$ in a REAX2 mixerrotator (Heidolph; Fisher Scientific Inc.), and left to settle for $5 \mathrm{~min}$. The supernatant $(1 \mathrm{ml})$ was used to start a 10-fold dilution series (from $10^{-1}$ to $10^{-4}$ ) and $50 \mu \mathrm{l}$ of each dilution was plated on duplicate plates of modified SMSA medium (Engelbrecht 1994). After incubation for $72 \mathrm{~h}$ at $28^{\circ} \mathrm{C}, R$. solanacearum colonies were counted, and the number of viable cells in the soil at the time of sampling was estimated from the count. The $R$. solanacearum colonies isolated from the soil were further confirmed by Pmx-PCR and Mmx-PCR analysis, as described by Prior and Fegan (2005). To count the $R$. solanacearum population as CFU/g of dry soil, soil moisture was recorded at each sampling date. Two 10-g samples of soil were removed from each bag and oven dried at $130^{\circ} \mathrm{C}$ for $24 \mathrm{~h}$ to measure soil moisture. Each treatment was replicated five times, using two plates per replicate, and the average of the two plates was calculated, giving a total of 240 observations.

Disease control. The development of bacterial wilt was assessed in tomato plants growing in inoculated soil treated with emulsified essential oil. The incidence of bacterial wilt was calculated as the percentage of wilted plants among all the tomato plants. Wilted tomato plants were first sampled to isolate $R$. solanacearum on modified SMSA medium. Suspected colonies of $R$. solanacearum were confirmed by Pmx-PCR and Mmx-PCR analysis, as described by Prior and Fegan (2005). At the end of the experiment (4 weeks after the tomato plants were transplanted), the presence of $R$. solanacearum on remaining and asymptomatic tomato plants was assessed on the basal part of the stem and the colonization index was calculated. Each treatment was replicated three times. One replicate consisted of 14 pots (each containing one plant), giving a total of 2,184 observations.

Growth of tomato plants. The height (in centimeters) of the tomato plants was measured 14, 17, 21, 24, 28, and 33 days after transplantation of the tomato plants to the soil treated with essential oil. At the end of the experiment (6 weeks after transplantation), tomato plants were uprooted, washed thoroughly to remove any remaining soil, and blotted dry with paper towels. The fresh weight of shoots and roots was determined. The plants were then dried at $60^{\circ} \mathrm{C}$ for $72 \mathrm{~h}$ for determination of the dry weight of the shoots and roots. Each 
treatment was replicated four times. One replicate consisted of 5 pots (each containing one plant), giving a total of 560 observations).

Data analysis. All in vitro tests were set up in a completely randomized design and each test was repeated twice. When there was no significant difference between trials, the data from the two trials were combined for analysis. All in vivo tests were set up in a randomized complete block design. Statistical analyses were performed using the SAS package (SAS version 9.3; SAS Institute Inc.). PROC GLM (general linear model) and PROC MIXED (mixed model) were used to conduct analysis of variance (ANOVA). To examine changes in soil population density of $R$. solanacearum in each treatment over time, we used Student's test ( $t$ test) for the differences of least squares means in the PROC MIXED statement. The means of the treatments at any single date were compared using the Student-Newman-Keuls test $(P<0.05)$.

\section{Results}

Effect of chemotype on in vitro growth $R$. solanacearum. To test the effect of the chemotype of $P$. racemosa var. racemosa, we measured in vitro growth of $R$. solanacearum on agar plates amended with different concentrations of each chemotype.

Chemotype 3 was the most effective in inhibiting $R$. solanacearum growth, followed by chemotype 1 and then chemotype 2 (Fig. 1). After $48 \mathrm{~h}$ of incubation at $28^{\circ} \mathrm{C}$, no growth of $R$. solanacearum was observed on plates amended with chemotype 3 at any of the concentrations tested, or on plates amended with chemotypes 1 and 2 at a concentration of
$0.14 \%$ emulsified essential oil. Some growth was observed on plates amended with concentrations of $0.04 \%(7.15 \mathrm{log} \mathrm{CFU} / \mathrm{ml})$ and $0.07 \%(6.25 \log \mathrm{CFU} / \mathrm{ml})$ chemotype 1 but, in both cases, the populations of $R$. solanacearum were significantly lower than in the control (7.96 log CFU/ml, $P<0.05$, Student-Newman-Keuls test). At a concentration of $0.04 \%(7.83 \log \mathrm{CFU} / \mathrm{ml})$ chemotype 2 , no significant difference was observed in $R$. solanacearum populations between the amended treatment and the control $(P>0.05$, Student-Newman-Keuls test) whereas, at a concentration of $0.07 \%$ (7.28 $\log \mathrm{CFU} / \mathrm{ml}$ ) chemotype 2, populations of $R$. solanacearum were significantly fewer than in the control $(P<0.05$, StudentNewman-Keuls test). The results of the statistical analysis of the two experimental trials showed that the chemotype (ANOVA: $F=3753.53$, $\mathrm{df}=3, P<0.0001$ ), the concentration of the chemotype (ANOVA: $F=$ 7399.08, $\mathrm{df}=1, P<0.0001$ ), and the interaction between the chemotype and the concentration (ANOVA: $F=848.51$, df $=5, P<0.0001$ ) had significant effects on the growth of $R$. solanacearum.

Determination of the minimum inhibitory concentration of chemotype 3. To identify the minimum inhibitory concentration, we measured in vitro growth of $R$. solanacearum in the presence of the chemotype 3 at concentrations of $0,0.01,0.02,0.03$, and $0.04 \%(\mathrm{v} / \mathrm{v})$ emulsified essential oil. The minimum inhibitory concentration of chemotype 3 was $0.03 \%$ emulsified essential oil (Fig. 2). After $48 \mathrm{~h}$ of incubation at $28^{\circ} \mathrm{C}$, no $R$. solanacearum grew on plates amended with chemotype 3 at a concentration of $0.03 \%$ emulsified essential oil. At a concentration of $0.01 \%(7.94 \log \mathrm{CFU} / \mathrm{ml})$ chemotype 3 ,

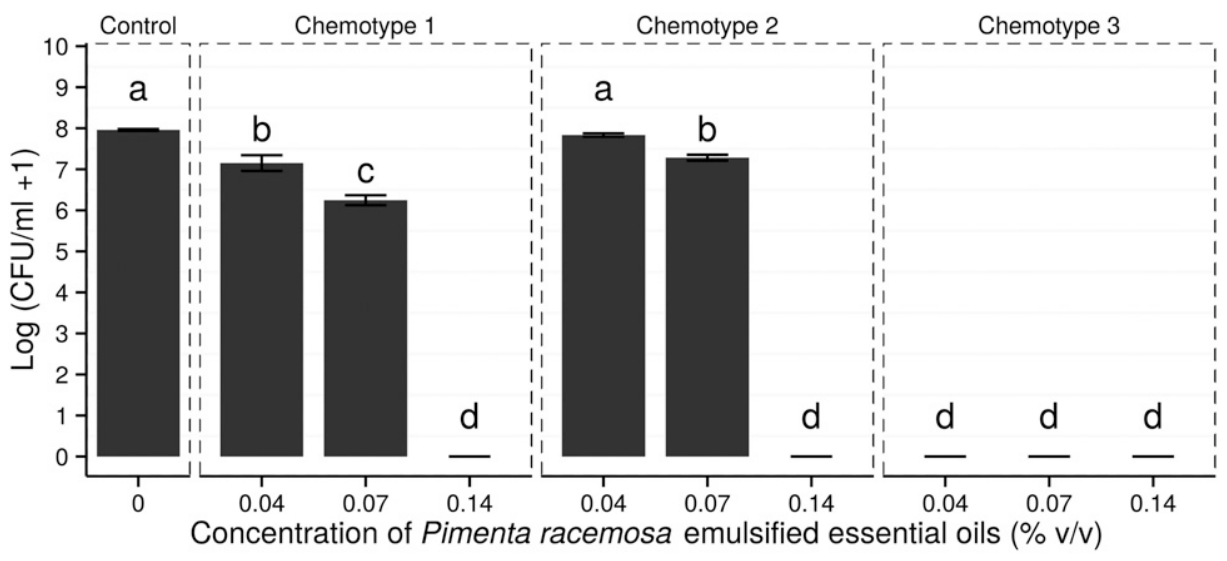

Fig. 1. Effect of three chemotypes of Pimenta racemosa var. racemosa emulsified essential oil on in vitro growth of Ralstonia solanacearum phylotype IIB/4NPB on SMSA medium after $48 \mathrm{~h}$ of incubation at $28^{\circ} \mathrm{C}$. Results of two experimental trials are shown. Means $(n=6)$ with different letters are significantly different at $P<0.05$ according to the StudentNewman-Keuls test. Error bars indicate the standard error of the mean. Chemotype $1=$ lemongrass-scented chemotype, chemotype $2=$ aniseed-scented chemotype, and chemotype 3 = clove-scented chemotype.

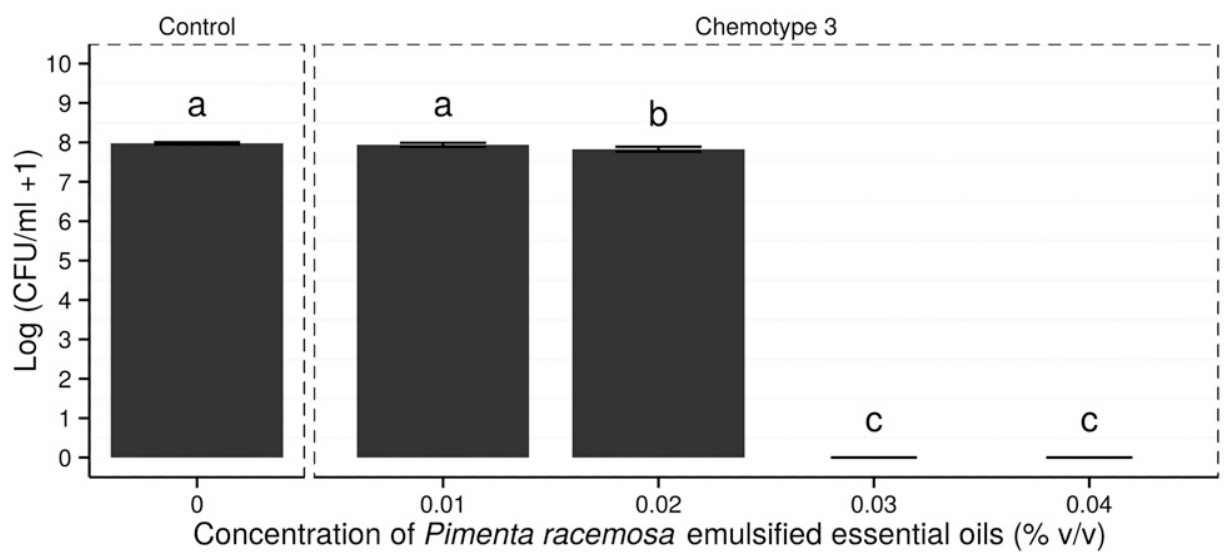

Fig. 2. Effect of the concentration of chemotype 3 of Pimenta racemosa var. racemosa emulsified essential oil on in vitro growth of Ralstonia solanacearum phylotype IIB/4NPB on SMSA medium after $48 \mathrm{~h}$ of incubation at $28^{\circ} \mathrm{C}$. Results of two experimental trials are shown. Means $(n=6)$ with different letters are significantly different at $P<0.05$ according to the Student-Newman-Keuls test. Error bars indicate the standard error of the mean. Chemotype $3=$ clove-scented chemotype. 
no significant difference was observed in $R$. solanacearum populations between the amended treatment and the control $(P>0.05$, Student-Newman-Keuls test) whereas, at a concentration of $0.02 \%$ (7.83 log CFU/ml) chemotype 3, the number of populations was significantly fewer $(P<0.05$, Student-Newman-Keuls test) than in the control. The results of the statistical analysis of the two experimental trials showed that the concentration of chemotype 3 (ANOVA: $F=$ 2486, df $=4, P<0.0001$ ) had a marked effect on the growth of $R$. solanacearum. After $72 \mathrm{~h}$ of incubation, there was no growth in either of the two assays performed, as indicated by the absence of any new colonies of $R$. solanacearum in any of the treatments (data not shown).

Population density of $R$. solanacearum in soil treated with essential oil. Because chemotype 3 was demonstrated to be the most effective in the in vitro studies, this chemotype was used for the pot studies. To test the effect of chemotype 3 as a preplant soil treatment on the population dynamics of $R$. solanacearum in the soil, the $R$. solanacearum population was enumerated during the experiment in soil treated with different concentrations of this chemotype. In the untreated control, the population of $R$. solanacearum increased significantly between day 0 and day 1 from 6.42 to $7.82 \log$ CFU/g dry soil $(P=0.0012, t$ test $)$, after which the population remained stable throughout the experiment, as shown by the lack of statistical difference in the density of the population of $R$. solanacearum $(P=$ $0.1923, t$ test) on day 1 and day 14 (Fig. 3). The results of statistical analysis showed that the concentration of emulsified essential oil of chemotype 3 had a significant effect on the population density of $R$. solanacearum in the soil from the first day after treatment with emulsified essential oil (ANOVA: $F=109.95$, df $=3, P<0.0001$ ). Between the day essential oil was applied (day 0 ) and the end of the experiment (corresponding to day 14 after treatment with emulsified essential oil) at the concentration of $0.07 \%$, population densities of $R$. solanacearum declined from 6.59 to $3.15 \mathrm{log}$ CFU/g of dry soil $(P<0.0001, t$ test $)$ and, at the concentration of $0.14 \%$, population densities declined from 6.33 to $1.57 \mathrm{log}$ CFU/g of dry soil $(P<$ $0.0001, t$ test). At the concentration of $0.04 \%$, the treatment had no effect on $R$. solanacearum and population densities remained high (6.62 to $6.16 \log$ CFU/g of dry soil; $P=0.2507, t$ test). In soils treated at the concentrations of $0.07 \%(P=0.0989, t$ test $)$ and $0.14 \%(P=$ $0.0351, t$ test), no significant decline in the populations of the pathogen in the soil was observed between day 0 , when the essential oil was applied, and day 7. However, 3 days after the incubation (i.e., on day 10 after the soil was treated with emulsified essential oil), the population of $R$. solanacearum was significantly lower in the soils treated at the concentrations of $0.07 \%(P=0.0066, t$ test $)$ and $0.14 \%(P=0.0008$, $t$ test) when compared with population density at the time of application. At the end of the experiment (corresponding to day 14 after treatment of the soil with emulsified essential oil), the concentration of chemotype 3 had a significant effect on the population density of $R$. solanacearum in the soil (ANOVA: $F=17.91$, df $=3, P<0.0001$ ). Populations of $R$. solanacearum were significantly fewer in the soil treated at the concentrations of 0.07 and $0.14 \%$ than in the untreated control $(P<0.05$, Student-Newman-Keuls test).

Disease control in soil treated with essential oil. Chemotype 3 at the concentration of $0.14 \%$ was found to be effective against tomato bacterial wilt, because tomato plants displayed complete resistance to $R$. solanacearum, the next most effective concentration being $0.07 \%$ (Fig. 4). Typical bacterial wilt symptoms were observed on day 7 after the tomato plants were transplanted. The incidence of bacterial wilt progressed rapidly between day 7 and day 12 in all of the treatments, except at the concentration of $0.14 \%$ chemotype 3 , in which no symptoms were observed. We then confirmed that wilted plants were infected with $R$. solanacearum phylotype IIB/4NPB by isolating the pathogen and performing PCR. At the end of the experiment (28 days after transplantation), the effect of the concentration of chemotype 3 on disease incidence was significant (ANOVA: $F=80.57$, $\mathrm{df}=3, P<0.0001)$. At the concentration of $0.14 \%$, none of the tomato plants showed any disease symptoms and remained healthy whereas, in the untreated control, $62 \%$ of plants showed symptoms of wilt. At the concentrations of 0.04 and $0.07 \%$, the final incidence of bacterial wilt was significantly lower $(P<0.05$, Student-NewmanKeuls test) than that of the untreated control: during the course of the experiment, only $23 \%$ of the plants wilted at the $0.07 \%$ concentration and $32 \%$ wilted at the $0.04 \%$ concentration of chemotype 3 . Four weeks after transplantation, no $R$. solanacearum was detected in the main stems near the base of the tomato plants at the concentration of $0.14 \%$, whereas $R$. solanacearum was detected in $76 \%$ of untreated plants. At the concentration of $0.07 \%, 30 \%$ of plants were latently infected but significantly less $(P<0.05$, Student-NewmanKeuls test) than in the untreated control. At the concentration of $0.04 \%, 65 \%$ of the plants were latently infected (i.e., not significantly different from the untreated control; $P>0.05$, Student-NewmanKeuls test).

Growth of tomato plants in soil treated with essential oil. Tomato plants grown in soils pretreated with chemotype 3 at the concentration of $0.14 \%$ were significantly taller and produced significantly more root and shoot biomass than the untreated control plants and the other concentrations of essential oil tested (Fig. 5). The effect of the concentration of chemotype 3 on plant height was significant (ANOVA: $F=21.48, \mathrm{df}=3, P<0.0001$ ) at the first assessment date,

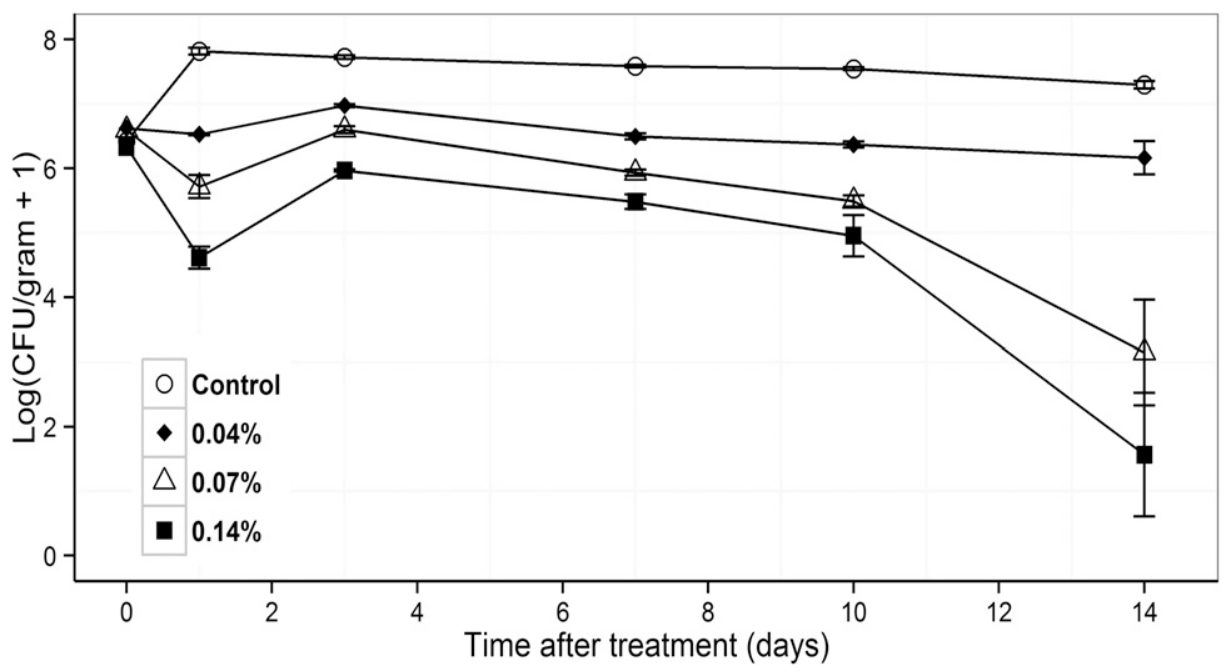

Fig. 3. Survival of Ralstonia solanacearum phylotype IIB/4NPB in artificially infested soil after treatment with different concentrations $(0.04,0.07$, and $0.14 \%)$ of chemotype 3 of Pimenta racemosa var. racemosa emulsified essential oil. Viable cells grown on SMSA medium are reported as log CFU per gram of dry soil +1 . Infested soil not treated with essential oil was used as control. Values in the figure represent means of five replications. Standard errors of the means are shown by vertical bars. 
10 days after the tomato plants were transplanted. At the concentration of $0.14 \%$, plants were significantly taller $(16.27 \pm 0.49 \mathrm{~cm} /$ plant, $P<$ 0.05 , Student-Newman-Keuls test) than untreated controls (11.68 \pm $0.29 \mathrm{~cm} /$ plant). There was no difference in height between plants at the concentrations of 0.07 and $0.04 \%$ and the untreated control (Fig. 5). At the end of the experiment (33 days after transplantation), the effect of the concentration of chemotype 3 on plant height was significant (ANOVA: $F=21.84$, $\mathrm{df}=3, P<0.0001$ ). At the concentration of $0.14 \%$, plants were significantly taller $(50.64 \pm 3.07 \mathrm{~cm} /$ plant, $P<$ 0.05 , Student-Newman-Keuls test) than untreated controls $(26.82 \pm$ $1.41 \mathrm{~cm} /$ plant). The concentration of $0.14 \%$ increased plant height by $88.8 \%$ (Fig. 5). The effect of the concentration of chemotype 3 on root weight (ANOVA: $F=14.23$, df $=3, P<0.0003$ ) and on shoot weight (ANOVA: $F=28.58, \mathrm{df}=3, P<0.0001$ ) was also significant at the end of the experiment. Treatment at the concentration of $0.14 \%$ resulted in the highest root weight $(2.06 \pm 0.34$ g per plant, $P<0.05$, StudentNewman-Keuls test) and highest shoot weight $(12.62 \pm 1.58$ g per plant, $P<0.05$, Student-Newman-Keuls test) (Table 1).

\section{Discussion}

Management of tomato bacterial wilt disease is currently extremely difficult due to the absence of effective chemical treatments for disinfecting $R$. solanacearum-infested fields, and the emerging $R$. solanacearum population (phylotype IIB/4NPB) that has been reported to overcome the main international sources of resistance used to create tomato cultivars resistant to bacterial wilt (Lebeau et al. 2011; Wicker et al. 2009a). Our study is the first to examine the effect of $P$. racemosa var. racemosa emulsified essential oil on the plantpathogenic bacterium $R$. solanacearum, and the possibilities of this oil to be used as a new natural product for development of a soil biofumigant to control bacterial wilt disease. We assessed the in vitro antibacterial activities of the three chemotypes of $P$. racemosa var. racemosa against $R$. solanacearum phylotype IIB/4NPB by enumerating populations of $R$. solanacearum on modified SMSA medium amended with different concentrations of the emulsified essential oils.

Our results demonstrated that chemotype 3 of essential oil of $P$. racemosa var. racemosa can suppress growth of $R$. solanacearum phylotype IIB/4NPB in vitro and that, depending on the concentration used, the essential oil can either protect tomato plants from infection by the bacterium or greatly reduce the incidence of bacterial wilt in greenhouse conditions. The antibacterial effect of chemotype 3 was confirmed by in vivo assays. Populations of $R$. solanacearum in the soil were the lowest when the soil was treated with concentrations

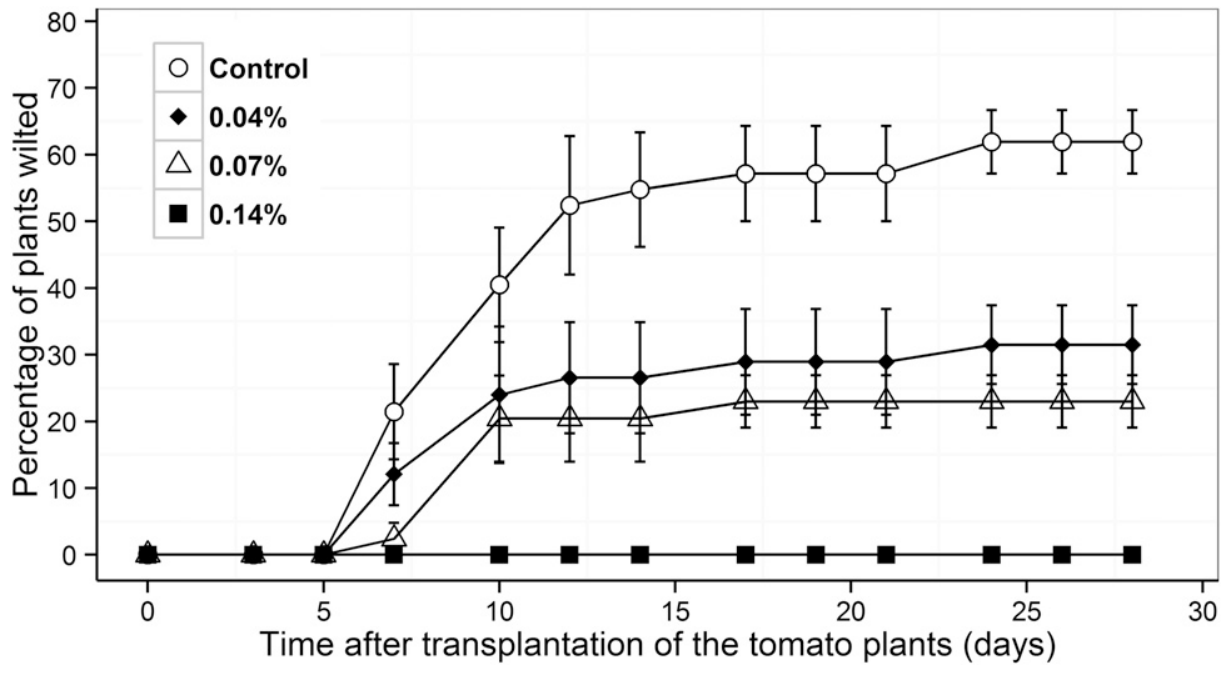

Fig. 4. Incidence of bacterial wilt on Heatmaster tomato grown in soil treated with three concentrations $(0.04,0.07$, and $0.14 \%)$ of chemotype 3 of Pimenta racemosa var. racemosa emulsified essential oil. Infested natural soil not treated with essential oil was used as control. Values in the figure represent means of 42 replicates. Standard errors of the means are shown by vertical bars.

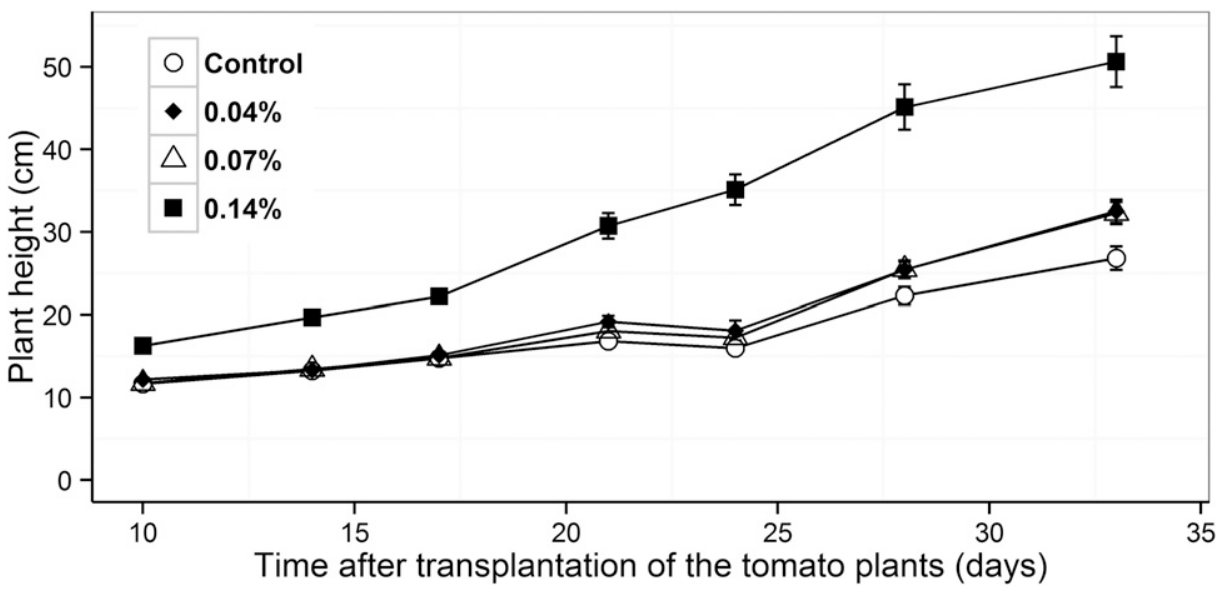

Fig. 5. Effect of soil treatment with three concentrations $(0.04,0.07$, and $0.14 \%)$ of chemotype 3 of Pimenta racemosa var. racemosa emulsified essential oil on the height of Heatmaster tomato. Natural soil not treated with essential oil was used as control. Values in the figure represent means of 20 replicates. Standard errors of the means are shown by vertical bars. 
of 0.07 and $0.14 \%$ chemotype 3 of $P$. racemosa var. racemosa emulsified essential oil before the tomato plants were transplanted. At a concentration of $0.14 \%$, all the tomato plants remained healthy until the end of the experiments, and no symptoms of bacterial wilt were recorded, whereas, at a concentration of $0.07 \%$ chemotype $3,23 \%$ the plants wilted. One possible reason for the $23 \%$ rate of wilt at the concentration of $0.07 \%$ is that the density of $R$. solanacearum populations may have remained sufficiently high in the soil to ensure the successful infection of the tomato plants. This could be because $R$. solanacearum cells were in a viable but nonculturable (VBNC) state induced in soil treated with $P$. racemosa var. racemosa essential oil. This hypothesis could also explain the results on day 1, when populations of $R$. solanacearum decreased in soil treated with the emulsified essential oil. When cells are exposed to stress caused, for example, by low temperatures, heavy metal, or starvation, they may enter the VBNC state (Gauthier 2000). In R. solanacearum, the VBNC state has been reported in several studies (Grey and Steck 2001; Imazaki and Nakaho 2010). VBNC cells have been shown to lose their ability to grow on standard media but some of the cells subsequently recovered this ability on media supplemented with sodium pyruvate (Imazaki and Nakaho 2010), which degrades hydrogen peroxide. All of the revived cells caused wilt symptoms in tomato plants, suggesting that the pathogenicity of $R$. solanacearum was maintained throughout cell-state transitions. Imazaki and Nakaho (2010) developed a pyruvateamended modified SMSA medium to improve the sensitivity of the detection of $R$. solanacearum by rescuing a portion of the VBNC cells. This selectively modified SMSA could be used to facilitate the recovery of pathogenic VBNC cells. However, more research is needed for a better understanding of the impact of $P$. racemosa var. racemosa essential oil on the induction of the VBNC state in $R$. solanacearum.

Our findings concerning the suppression of bacterial wilt by $P$. racemosa var. racemosa emulsified essential oil are in agreement with previous reports stating that essential oils reduced bacterial wilt disease. Pradhanang et al. (2003) showed that essential oils of palmarosa and lemongrass reduced populations of $R$. solanacearum race 1 strains in potting medium and suppressed bacterial wilt of tomato, and Paret et al. (2010) demonstrated the bactericidal effect of the same essential oils (palmarosa and lemongrass oils) on $R$. solanacearum race 4 strains, which cause bacterial wilt of edible ginger in tropical areas. The use of palmarosa oil and thymol as biofumigants for the management of bacterial wilt has also been evaluated in field conditions (Ji et al. 2005, 2007). Huang and Lakshman (2010) demonstrated that clove essential oil has the potential to eliminate populations of $R$. solanacearum in soil and to greatly reduce the incidence of bacterial wilt of tomato and geranium in greenhouse conditions. More recently, soil biofumigation with palmarosa essential oil reduced the severity of bacterial wilt of sweet pepper in both the greenhouse and the field (Alves et al. 2014).

In the present study, no phytotoxic effects were observed on tomato plants after transplantation to treated soil. This is the first observation of positive effects of essential oils and, in particular, of $P$. racemosa var. racemosa emulsified essential oil on tomato growth in addition to the suppressive effect of essential oils on $R$. solanacearum populations in soil and on bacterial wilt disease.

Plants produce a battery of antimicrobial compounds, which play roles in plant development and interactions with microbes. Essential oils extracted from plants are composed of a range of bioactive compounds that are associated with antimicrobial activities (Bajpai et al. 2009; Bi et al. 2012; Burt 2004; Kim et al. 2008; Kishore et al. 2007; Lucas et al. 2012; Moghaddam et al. 2014). Many bacteria can survive and even grow in the presence of toxic host defense compounds because they apply multiple strategies to evade the defense compounds produced by the plant. Studies have shown that $R$. solanacearum protects itself with multidrug efflux pumps or enzymatically degrades plant defense compounds such as reactive oxygen species and hydroxycinnamic acids (Brown et al. 2007, Flores-Cruz and Allen 2009; Lowe et al. 2015). Our findings that $P$. racemosa var. racemosa-emulsified essential oil inhibited growth of $R$. solanacearum and suppressed bacterial wilt of tomato suggest that bioactive compounds produced by $P$. racemosa var. racemosa are inhibitory or toxic for $R$. solanacearum and that $R$. solanacearum cannot infect or spread in this host and cause disease because of the absence of a strategy to evade the compounds produced by this plant species. This hypothesis is supported by the absence of reports in the literature on $P$. racemosa var. racemosa as a susceptible host of $R$. solanacearum.

Analysis of the essential oils of the three chemotypes of $P$. racemosa var. racemosa from Guadeloupe (French West Indies) revealed differences between their physical characteristics and their chemical compositions (Abaul and Bourgeois 1995); large quantities of phenolic ethers (eugenol, chavicol, estragole, and methyleugenol) were found in chemotypes 2 and 3, whereas chemotype 1 mainly contained acyclic oxygenated monoterpenes such as geranial and neral. The essential oils tested in our study were extracted using the same hydrodistillation method as that described by Abaul and Bourgeois (1995). These authors reported that a clove-scented chemotype (chemotype 3) contains 29 compounds, of which eugenol is the major component and chavicol and linalol are minor compounds (Abaul and Bourgeois 1995). Their results were confirmed by the results we obtained in a recent study in which we identified eugenol as the main component in chemotype 3 (P. Deberdt, unpublished data). Previous studies reported that the antibacterial mode of action of eugenol is disruption of the bacterial cell membrane, which increases its nonspecific permeability. Hyperpermeability results in leakage of ions and extensive loss of other cell contents, including intracellular proteins, and ultimately results in cell death (Devi et al. 2010; Gill and Holly 2006). Huang and Lakshman (2010) suggested that eugenol, which was the main component of the clove essential oil used in their study, may be the major contributor to the antibacterial properties of this oil. We also propose that the antimicrobial mode of action of chemotype 3 of $P$. racemosa var. racemosa essential oil could be linked to eugenol, which is reported in the literature to be the major component of this essential oil not only in the French West Indies (Abaul and Bourgeois 1995) but also in other parts of the world (Kim et al. 2008; Pragadheesh et al. 2013; Tchobo et al.2014). Epifluorescence microscopy is required to demonstrate the bactericidal properties of eugenol, as described by Paret et al. (2010).

The systemic resistance induced in tomato plants after treatment of the soil with essential oil could also explain the control of the disease observed in our study. Indeed, at a concentration of $0.04 \%$ chemotype 3 , only $32 \%$ of the plants wilted (corresponding to a disease reduction of $50 \%$ when compared with the control) even though the populations of $R$. solanacearum in the soil were not significantly reduced at the time of transplantation of tomato plants compared with the untreated control. A recent study by Wang and Fan (2014) demonstrated that eugenol greatly influenced tomato resistance to Tomato leaf curl virus. These authors showed that eugenol is an effective activator of induced plant systemic acquired resistance by triggering the salicylic acid biosynthesis pathway. The induction of

Table 1. Effects of soil treatment with chemotype 3 of Pimenta racemosa var. racemosa essential oil on the growth of the shoots and roots of Heatmaster tomato under greenhouse conditions 42 days after the plant was transplanted

\begin{tabular}{|c|c|c|c|}
\hline \multirow[b]{2}{*}{ Treatment } & \multirow[b]{2}{*}{ Concentration (\%) } & \multicolumn{2}{|c|}{$\begin{array}{l}\text { Dry weight (g per plant) } \\
\quad(\text { means } \pm \mathrm{SE})^{\mathrm{x}}\end{array}$} \\
\hline & & Shoots & Roots \\
\hline \multirow[t]{3}{*}{ Chemotype $3^{y}$} & 0.04 & $3.51 \pm 0.54 b$ & $0.70 \pm 0.10 b$ \\
\hline & 0.07 & $3.90 \pm 0.19 b$ & $0.75 \pm 0.07 \mathrm{~b}$ \\
\hline & 0.14 & $12.62 \pm 1.58 \mathrm{a}$ & $2.06 \pm 0.34 \mathrm{a}$ \\
\hline Control $^{\mathrm{z}}$ & $\ldots$ & $2.89 \pm 0.40 b$ & $0.57 \pm 0.06 b$ \\
\hline
\end{tabular}

$\mathrm{x}$ Values are the mean of 20 replicates. $\mathrm{SE}=$ standard error. Values in the same column followed by different letters are significantly different at $P<0.05$ according to the Student-Newman-Keuls test.

y Essential oils were emulsified in Tween 20 (ratio 1:1) and mixed with water. The emulsion was poured onto the soil and then mixed in. Pots were covered with aluminum sheets for 7 days and then left uncovered for a further 3 days. Tomato plantlets were planted 10 days after treatment with the emulsified essential oil.

${ }^{\mathrm{z}}$ Control: no $R$. solanacearum, no essential oil, the treatment included Tween, and the pots were covered. 
systemic resistance in Heatmaster tomato against bacterial wilt by chemotype 3 of $P$. racemosa var. racemosa essential oil can be evaluated by measuring the activity of defense-related enzymes and the activity of pathogenesis-related proteins, which are excellent molecular markers for the response of resistance to pathogens (Hassan et al. 2009; Wang and Fan 2014).

The effectiveness of chemotype 3 of $P$. racemosa var. racemosa essential oil in controlling bacterial wilt and the economics of its use under field conditions remain to be analyzed. Still, large-scale application of this essential oil to treat $R$. solanacearum-infested fields is probably not feasible due to its high price. As an alternative, amending the soil with freshly harvested leaves of $P$. racemosa var. racemosa to release volatiles of essential oils into pathogeninfested fields is an interesting possibility. Further research is now needed to study the effect of incorporating fresh leaves of $P$. racemosa var. racemosa into the soil on $R$. solanacearum populations and on the control of tomato bacterial wilt. Another possible approach that would reduce the cost of application would be to use the major active ingredients of this essential oil. For example, thymol, the main volatile compound in Thymus spp., has been used to reduce bacterial wilt of tomato in Florida (Hong et al. 2011; Ji et al. 2005, 2007; Pradhanang et al. 2003). Ji et al. (2005) evaluated thymol under inoculated field conditions and found that its application significantly reduced the incidence of bacterial wilt and increased the yield of a susceptible tomato cultivar. One way to reduce the quantity of thymol required for application at the field scale would be to include it in drip irrigation, as tested by $\mathrm{Ji}$ et al. (2007). These authors showed that the use of synthetically produced agricultural-grade thymol is economically feasible. This approach also needs to be evaluated using the major compounds of chemotype 3 of $P$. racemosa var. racemosa essential oil.

Before starting such studies, the chemical composition of chemotype 3 of $P$. racemosa var. racemosa used in this study needs to be published to confirm that eugenol is its main compound (P. Deberdt, unpublished data), as reported in the literature cited (Abaul and Bourgeois 1995); not only the antibacterial effects of the main component, eugenol, but also the synergistic or antagonistic effects of the combination of the major and minor components of chemotype 3 need to be investigated.

Our experiments using chemotype 3 of $P$. racemosa var. racemosa emulsified essential oil showed that this oil inhibited growth of $R$. solanacearum phylotype II/4NPB in vitro, and inhibited bacterial wilt disease while increasing tomato growth in greenhouse conditions. Consequently, chemotype 3 of $P$. racemosa var. racemosa essential oil can be included in a biorationale approach for management of tomato bacterial wilt in greenhouse conditions. Further studies are needed to (i) confirm our results in field conditions and to assess the effect of chemotype 3 of $P$. racemosa var. racemosa essential oil on tomato yield and (ii) further investigate the antibacterial effects of the major compounds of chemotype 3 used in this study on $R$. solanacearum.

\section{Acknowledgments}

This research was supported by the European Union (FEDER project) and the Conseil Régional de la Martinique. We thank G. M. Balestra, Department for Agriculture, Forestry, Nature and Energy, University of Tuscia, Italy, for his critical review of the manuscript.

\section{Literature Cited}

Abaul, J., and Bourgeois, P. 1995. Chemical composition of the essential oils of chemotypes of Pimenta racemosa var. racemosa (P. Miller) J. W. Moore (Bois d'Inde) of Guadeloupe (F.W.I). Flavour Fragrance J. 10:319-321.

Abdel-Monaim, M. F., Abo-Elyousr, K. A. M., and Morsy, K. M. 2011. Effectiveness of plant extracts on suppression of damping-off and wilt diseases of lupine (Lupinus termis Forsik). Crop Prot. 30:185-191.

Abo-Elyousr, K. A. M., and Asran, M. R. 2009. Antibacterial activity of certain plant extracts against bacterial wilt of tomato. Arch. Phytopathol. Plant Prot. 42:573-578.

Alves, A. O., Santos, M. M. B., Santos, T. C. G., Souza, E. B., and Mariano, R. L. R. 2014. Biofumigation with essential oils for managing bacterial wilt of sweet peppers. J. Plant Pathol. 96:363-367.

Aurore, G. S., Abaul, J., and Bourgeois, P. 1998. Antibacterial and antifungal activities of the essential oils of Pimenta racemosa var. racemosa P. Miller (J. W. Moore) (Myrtaceae). J. Essent. Oil Res. 10:161-164.
Bajpai, V. K., Cho, M. J., and Kang, S. C. 2010. Control of plant pathogenic bacteria of Xanthomonas spp. by the Essential Oil and Extracts of Meta sequoia glyptostroboides Miki ex Hu In vitro and in vivo. J. Phytopathol. 158: 479-486.

Bajpai, V. K., Lee, T., and Kang, S. 2009. Chemical composition and in vitro control of agricultural plant pathogens by the essential oil and various extracts of Nandina domestica Thunb. J. Sci. Food Agric. 89:109-116.

Balestra, G. M., Heydari, A., Ceccarelli, D., Ovidi, E., and Quattrucci, A. 2009. Antibacterial effect of Allium sativum and Ficus carica extracts on tomato bacterial pathogens. Crop Prot. 28:807-811.

Bi, Y., Jiang, H., Hausbeck, M. K., and Hao, J. J. 2012. Inhibitory effects of essential oils for controlling Phytophthora capsici. Plant Dis. 96:797-803.

Bowers, J. H., and Locke, J. C. 2004. Effect of formulated plant extracts and oils on population density of Phytophthora nicotianae in soil and control of Phytophthora blight in the green house. Plant Dis. 88:11-16.

Brown, G. G., Swanson, J. K., and Allen, C. 2007. Two host-induced Ralstonia solancaerum genes, acrA and $\operatorname{din} F$, encode multidrug efflux pumps and contribute to bacterial wilt virulence. Appl. Environ. Microbiol. 73:2777-2786.

Burt, S. 2004. Essential oils: Their antibacterial properties and potential applications in foods- a review. Int. J. Food Microbiol. 94:223-253.

Deberdt, P., Perrin, B., Coranson-Beaudu, R., Duyck, P., and Wicker, E. 2012. Effect of Allium fistulosum extract on Ralstonia solanacearum populations and tomato bacterial wilt. Plant Dis. 96:687-692.

Denny, T. 2006. Plant pathogenic Ralstonia species. Pages 573-644 in: PlantAssociated Bacteria. S. S. Gnanamanickam, ed. Springer, Dordrecht, The Netherlands.

Devi, K. P., Nisha, S. A., Sakthivel, R., and Pandian, S. K. 2010. Eugenol (an essential oil of clove) acts as an antibacterial agent against Salmonella typhi by disrupting the cellular membrane. J. Ethnopharmacol. 130:107-115.

Engelbrecht, M. C. 1994. Modification of a semi-selective medium for the isolation and quantification of Pseudomonas solanacearum. ACIAR. Bact. Wilt Newsl. 10:3-5.

Flores-Cruz, Z., and Allen, C. 2009. Ralstonia solanacearum encounters an oxidative environment during tomato infection. Mol. Plant-Microbe Interact. 22:773-782.

Gauthier, M. J. 2000. Environmental parameters associated with the viable but nonculturable state. Pages 87-112 in: Nonculturable microorganisms in the environment. R. R. Colwell and D. J. Grimes, eds. ASM Press, Washington, DC.

Gill, A. O., and Holly, R. A. 2006. Disruption of Escherichia coli, Listeria monocytogenes and Lactobacillus sakei cellular membranes by plant oil aromatics. J. Food Microbiol. 108:1-9.

Grey, B. E., and Steck, T. R. 2001. The viable but nonculturable state of Ralstonia solanacearum may be involved in long-term survival and plant infection. Appl. Environ. Microbiol. 67:3866-3872.

Griffin, S. G., and Markham, L. M. 2000. An agar dilution method for the determination of the minimum inhibitory concentration of essential oils. J. Essent. Oil Res. 12:249-255.

Hashem, M., Moharam, A. M., Zaied, A. A., and Saleh, F. E. M. 2010. Efficacy of essential oils in the control of cumin root rot disease caused by Fusarium spp. Crop Prot. 29:1111-1117.

Hassan, M. A. E., Bereika, M. F. F., Abo-Elnaga, H. I. G., and Sallam, M. A. A. 2009. Direct antimicrobial activity and induction of systemic resistance in potato plants against bacterial wilt disease by plant extracts. Plant Pathol. J. 25:352-360.

Hayward, A. C. 1991. Biology and epidemiology of bacterial wilt caused by Pseudomonas solanacearum. Annu. Rev. Phytopathol. 29:65-87.

Hendrick, C. A., and Sequeira, L. 1984. Lipopolysaccharide- defective mutants of the wilt pathogen Pseudomonas solanacearum. Appl. Environ. Microbiol. 48:94-101.

Hong, J. C., Momol, M. T., Pingsheng, J., Olson, S. M., Colee, J., and Jones, J. B. 2011. Management of bacterial wilt in tomatoes with tymol and acibenzolar-Smethyl. Crop Prot. 30:1340-1345.

Huang, Q., and Lakshman, D. K. 2010. Effect of clove oil on plant pathogenic bacteria and bacterial wilt of tomato and geranium. J. Plant Pathol. 92:701-707.

Imazaki, I., and Nakaho, K. 2010. Pyruvate-amended modified SMSA medium: Improved sensitivity for detection of Ralstonia solanacearum. J. Gen. Plant Pathol. 76:52-61.

Ji, P., Momol, M. T., Olson, S. M., Pradhanang, P. M., and Jones, J. 2005 Evaluation of thymol as biofumigant for control of bacterial wilt of tomato under field conditions. Plant Dis. 89:497-500.

Ji, P., Momol, M. T., Rich, J. R., Olson, S. M., and Jones, J. B. 2007. Development of an integrated approach for managing bacterial wilt and root-knot nematodes on tomato under field conditions. Plant Dis. 91:1321-1326.

Kim, J., Lee, Y. S., Lee, S. G., Shin, S. C., and Park, I. K. 2008. Fumigant antifungal activity of plant essential oils and components from West Indian bay (Pimenta racemosa) and thyme (Thymus vulgaris) oils against two phytopathogenic fungi. Flavour Fragrance J. 23:272-277.

Kishore, G. K., Pande, S., and Harish, S. 2007. Evaluation of essential oils and their components for broad-spectrum antifungal activity and control of late spot and crown rot diseases in peanut. Plant Dis. 91:375-379.

Lebeau, A., Daunay, M. C., Frary, A., Palloix, A., Wang, J. F., Dintinger, J., Chiroleu, F., Wicker, E., and Prior, P. 2011. Bacterial wilt resistance in 
tomato, pepper, and eggplant: Genetic resources respond to diverse strains in the Ralstonia solanacearum species complex. Phytopathology 101:154-165.

Lowe, T. M., Ailloud, F., and Allen, C. 2015. Hydroxycinnamic acid degradation, a broadly conserved trait, protects Ralstonia solanacearum from chemical plant defenses and contributes to root colonization and virulence. Mol. Plant-Microbe Interact. 28:286-297.

Lucas, G. C., Alves, E., Pereira, R. B., Zacaroni, A. B., Perina, F. J., and de Souza, R. M. 2012. Indian clove essential oil in the control of tomato bacterial spot. J. Plant Pathol. 94:45-51.

Moghaddam, M., Alymanesh, M. R., Mehdizadeh, L., Mirzaei, H., and Pirbalouti, A. G. 2014. Chemical composition and antibacterial activity of essential oil of Ocimum ciliatum, as a new source of methyl chavicol, against ten phytopathogens. Ind. Crops Prod. 59:144-148.

Paret, M. L., Cabos, R., Kratky, B. A., and Alvarez, A. M. 2010. Effect of plant essential oil on Ralstonia solanacearum race 4 and bacterial wilt of edible ginger. Plant Dis. 94:521-527.

Pradhanang, P. M., Momol, M. T., Olson, S. M., and Jones, J. B. 2003. Effects of plant essential oils on Ralstonia solanacearum population density and bacterial wilt incidence in tomato. Plant Dis. 87:423-427.

Pragadheesh, V. S., Yadav, A., Singh, S. C., Gupta, N., and Chanotiya, C. S. 2013. Leaf essential oil of cultivated Pimenta racemosa (Mill.) J. W. Moore from North India: Distribution of phenylpropanoids and chiral terpenoids. Med. Aromat. Plants 2:118.

Prior, P., and Fegan, M. 2005. Diversity and molecular detection of Ralstonia solanacearum race 2 strains by multiplex PCR. Pages 405-414 in: Bacterial Wilt Disease and the Ralstonia solanacearum Species Complex. C. Allen, P. Prior, and A. C. Hayward, eds. American Phytopathological Society, St Paul, MN.
Raut, J. S., and Karuppayil, S. M. 2014. A status review on the medicinal properties of essential oils. Ind. Crops Prod. 62:250-264.

Tchobo, F. P., Alitonou, G. A., Soumanou, M. M., Barea, B., Bayrasy, C., Laguerre, M., Lecomte, J., Villeneuve, P., and Souhounhloue, K. C. D. 2014. Chemical composition and ability of essential oils from six aromatic plants to counteract lipid oxidation in emulsions. J. Am. Oil Chem. Soc. 91:471-479.

Van Elsas, J., and Smalla, K. 1997. Methods for sampling soil microbes. Pages 383-390 in: Manual of Environmental Microbiology. C. J. Hurst, G. R Knudsen, M. J. McInerney, C. H. Stetzenbach, and M. V. Walter, eds. American Society for Microbiology Press, Washington, DC.

Wang, C., and Fan, Y. 2014. Eugenol enhances the resistance of tomato against tomato yellow leaf curl virus. J. Sci. Food Agric. 94:677-682.

Wicker, E., Coranson-Beaudu, R., Cadasse, S., and William, M.-A. 2009a. Emerging strains of Ralstonia solanacearum in the French West Indies raise new challenges to tomato breeders. Acta Hortic. 808:279-286.

Wicker, E., Grassart, L., Coranson-Beaudu, R., Mian, D., Guilbaud, C., Fegan, M. and Prior, P. 2007. Ralstonia solanacearum strains from Martinique (French West Indies) exhibiting a new pathogenic potential. Appl. Environ. Microbiol. 73:6790-6801.

Wicker, E., Grassart, L., Coranson-Beaudu, R., Mian, D., and Prior, P. 2009b. Epidemiological evidence for the emergence of a new pathogenic variant of Ralstonia solanacearum in Martinique (French West Indies). Plant Pathol. 58:853-861.

Yabuuchi, E., Kosako, Y., Yano, I., Hotta, H., and Nishiuchi, Y. 1995. Transfer of Burkholderia and an alcaligenes species to Ralstonia gen. nov.: Proposal for Ralstonia pickettii, Ralstonia solanacearum and Ralstonia eutropha. Microbiol. Immunol. 39:897-904. 